Creative Commons User License: CC BY-NC-ND

Abstracted by: EBSCOhost, Electronic Journals Service (EJS),

Google Scholar, Journal Seek, Scientific Commons,

Food and Agricultural Organization (FAO), CABI and Scopus

http://eoi.citefactor.org/10.11226/v25i1
Journal of Agricultural Extension

Vol. 25 (1) January, 2021

ISSN(e): 24086851; ISSN(Print); 1119944X

http://journal.aesonnigeria.org

http://www.ajol.info/index.php/jae

Email: editorinchief@aesonnigeria.org

\title{
Information and Communication Technologies Usage among Agricultural Students of Tertiary Institutions in Southwest of Nigeria
}

https://dx.doi.org/10.4314/jae.v25i1.1

Yekinni, Oyedeji.T.

Department of Agricultural Extension and Rural Development, University of Ibadan

E-mail: taofeegyekinni@gmail.com ; Phone: 08035905311

Ladigbolu, Temitope. A.

Department of Agricultural Extension and Rural Development, University of Ibadan

Email: adejojutemitope@gmail.com; Phone: 08035337569

Adeniyi, Rhoda. T.

Department of Agricultural Economics and Extension, Ajayi Crowther University, Oyo

Email: rt.adeniyi@yahoo.com; Phone: 08027640111

Oluwasusi, Sola. J.

Department of Agricultural Extension and Rural Development, University of Ibadan

Email:shola.small@yahoo.com Phone: 08067486413

\begin{abstract}
The study examined information and communication technologies usage among agricultural students of tertiary institution in Southwest of Nigeria. Multistage sampling procedure was used to select 300 agricultural students from tertiary institutions. Structured questionnaire was employed to elicit information on students' socioeconomic characteristics, availability of ICTs, accessibility and purposes of ICTs usage. Data were subjected to percentage, chi-square, the Pearson Product Moment Correlation and the Analysis of variance at $p=0.05$. Findings revealed that the most available ICTs among students were internet and mobile phone (95.0\%) respectively while they had access to mobile phone (Weighted Mean $(W M)=0.58$ ) and radio $(W M=0.51)$, they used ICTs for information $(W M=0.77)$, academics $(W M=0.70)$ and entertainment $(W M=0.70)$ purposes; with high level of availability (71.0\%), access (56.7\%) and ICTs usage purpose (51.3\%) respectively. There were significant relationships between respondents' monthly stipend $(r=0.200)$, state of institution $(x 2=8.000)$, religion $(x 2=222.660)$, marital status $(x 2=211.680)$, category of students' programme $(x 2=320.4608)$, type of institution $\left(X^{2}=56.000\right)$ and their purposes for using ICTs but with a significant difference across the states ( $F=23.821 ; p=0.00)$. Students used ICTs for information, academic and entertainment purposes based on their age and type of their institutions. Since ICTs are used for beneficial purposes, it is recommended that ICTs should be adapted, applied and incorporated into tertiary institutions' curricula across the nation.
\end{abstract}

Keywords: ICTs usage, undergraduate students, entertainment purposes, mobile phone, tertiary institutions. 
Creative Commons User License: CC BY-NC-ND

Abstracted by: EBSCOhost, Electronic Journals Service (EJS),

Google Scholar, Journal Seek, Scientific Commons,

Food and Agricultural Organization (FAO), CABI and Scopus

http://eoi.citefactor.org/10.11226/v25i1
Journal of Agricultural Extension

Vol. 25 (1) January, 2021

ISSN(e): 24086851; ISSN(Print); 1119944X

http://journal.aesonnigeria.org

http://www.ajol.info/index.php/iae

Email: editorinchief@aesonnigeria.org

\section{Introduction}

ICT has been found to be a developmental tool for developed and developing nations, as it is known for propagation of information. It is vital to all the sectors of economy especially the educational sector that has been said to be a cardinal point to sustainable development. Sequel to the above, ICTs have been found to be useful and influential instruments for achieving quality research in teaching and learning activities. These academics activities are being carried out both within and outside the four walls of the classroom even right from the cradle to higher institution of learning. Information via ICT has been an indispensable resource employed daily both by governmental and non-governmental organisations of learning in Nigeria. The global inevitability of technology as a powerful tool has made it relevant in every aspect of students' life especially at the tertiary level; as it allows and enable successful accomplishment of their academic task and for the establishment of sustainable educational development (Namita, 2017; Hamilton-Ekeke and Mbachu, 2015).

The development brought about by information and communication technologies (ICTs) to learning process increases and sustains the interest and knowledge of academics, non-academics and students of higher institutions in Nigeria to forge ahead in their pursuit of their respective career as the rate of ICT coverage increases daily. According to Golam, Arifa, Iqbal Hasan, Arifur (2015) the available and accessible ICTs (hardware and soft devices) for students of higher institution of learning in developing nations do allow their active involvement in the learning processes, the devices used to achieve these include printers, projectors, scanners, mobile phone, lap top, radio, television, newspaper, bulletin, magazine, ipod, desktop, satellite communication devices, computer, internet, e-mail address, CDRom, projector, scanner, printer, playbook, ipad among others. These ICT has been found resourceful for information management (gather, analyse, store, transfer and present data among others) in the areas of commerce, law, engineering, aviation, finance, medicine, architecture, banking and finance, insurance, and of agricultural activities among others. The relevance and high demand for its usage has made it to be a companion of the students in all fields of study including the potential agricultural experts at all cadre of higher institution of learning (Orifah, ljeoma, Olajide, and Wigwe, 2017 and Onodugo, 2016).

Application of ICT in all the scopes of agriculture are essential for enriching the students' total knowledge and networking in their course of study. This has worked well in countries like Korea, Japan, India, Malaysia and China among others. Hence, the significance of ICT to agricultural students' career cannot be over emphasised as it has the capacity of exposing them to theoretical and practical knowledge (animal husbandry, fisheries, agricultural mechanisation, cultural practices in crop production, and forestry among others) needed for proper attitude and skills to be built for their agricultural vocation. This knowledge might not be easily acquired in the classroom or might be constrained by the status of infrastructural facilities available for such aspect. therefore, ICT gives a noble opportunity for learning systems where an information could be timely shared using different format (video, 
music, chat,); they could as well go over the retrieved and stored information severally especially when it is found innovative, relevant, reliable and accurate. ICT facilitates the automation of agricultural students' mental activities for critical thinking and building capacities that is coupled with problem solving abilities. However, the availability and the accessibility of the ICTs for the agricultural students in higher institution will project the purpose(s) to which the tools are put to use (Adavbiele, 2016).

Several authors have studied the use of ICTs among categories of users in Nigeria and other climes (Orifah et al, 2017; Adavbiele, 2016; Hamilton-Ekeke and Mbachu, 2015) however, it is important to probe the specific reasons agricultural students of higher institutions users employ each ICTs. Hence, the study investigated purposes of Information and Communication Technologies usage among agricultural students of tertiary institution in Southwest of Nigeria. The study examined the available ICTs, accessible ICTs, and the ICTs usage purpose. It was hypothesised that no significant relationship existed between the selected socioeconomic characteristics and the ICT usage purpose; no significant difference in students' ICTs usage purposes across the state and; that there is no significant difference in students' ICTs usage purposes across the Institutions.

\section{Methodology}

The study was carried out in Southwest zone of Nigeria. Southwest lies between latitude $6030^{\prime} \mathrm{N}$ to $9^{\prime} \mathrm{N}$ and longitude $300^{\prime} \mathrm{E}$ to $5030^{\prime} \mathrm{E}$. Multistage sampling procedure was used to select students for the study. The first stage involved the simple random selection of three of the six states in the zone; the selected states are Ekiti, Oyo, and Ondo. The second stage involved the stratification of the institutions in the selected states into University, Polytechnic and College of education. Ekiti State had three Universities (UNI), one Polytechnic (POLY) and one College of education (COE); Oyo state had four UNI, five POLY and three COE, while Ondo state had four UNI, one POLY and one COE. In the third stage simple random sampling was adopted to select $50 \%$ of the selected UNI, POLY and COE in the selected states respectively. Hence, four, seven and four institutions were selected in Ekiti state (two UNI, one POLY and one COE); Oyo (two UNI, three POLY, two $\mathrm{COE}$ ) and Ondo State (two UNI, one POLY and one COE) respectively. The fourth stage involved simple random selection of one department in the Faculty of Agriculture in the selected institutions. The fifth stage involved simple random selection of (a quota) twenty (20) students using the final year list of 2011/2012 from the selected Departments of the sampled fifteen tertiary institutions, which gave a sample size of 300 respondents.

Data were collected using structured questionnaire and were subjected to percentage, chi-square, the Pearson Product Moment Correlation (PPMC) and the Analysis of variance (ANOVA) at $\alpha 0.05$

Availability of the ICT tools was measured by providing respondents with eighteen ICTs that could be available to them in the study area with the response options of 'available' and 'not available with score of 1 and 0 respectively. Thereafter, the ICTs 
Creative Commons User License: CC BY-NC-ND

Abstracted by: EBSCOhost, Electronic Journals Service (EJS),

Google Scholar, Journal Seek, Scientific Commons,

Food and Agricultural Organization (FAO), CABI and Scopus
Journal of Agricultural Extension

Vol. 25 (1) January, 2021

ISSN(e): 24086851; ISSN(Print); 1119944X

http://journal.aesonnigeria.org

http://www.ajol.info/index.php/jae

Email: editorinchief@aesonnigeria.org

with highest frequency was determined and used to rank them. The ICT with the highest mean score of was ranked first while the ICT with the lowest mean score was ranked the least available ICT to the respondents respectively.

Eighteen ICTs that could be possibly accessible to the students with response options of "all the time", "some of the time" and "not at all" were provided to measure respondents access to the available ICTs. The response options were assigned scores of 2, 1 and 0 in that order. First of all, weighted mean for each ICT item was computed and used in ranking the items in descending order. An index of access to the available ICT component was generated and was used to categorised respondents into high and low level of access using the 'above and below the mean' criterion. The mean score of the respondents' access to available ICTs was 22.5 therefore respondents with scores above 22.5 had high level of accessibility and vice versa.

Respondents' purpose of ICTs usage was measured by providing the respondents with possible reasons they could be using their ICTs. Some of the reasons are for news, entertainment, relaxation, academic purpose among others. They were provided with four response options of "not at all', 'rarely', sometimes' and 'all the times'. The response options were assigned scores of $0,1,2$ and 3 in that order. Firstly, the weighted mean for each ICT item was computed and used in ranking the items in descending order. An index of ICT's usage purpose was generated and was used to categorised respondents into high and low level of ICT'S usage purpose using the 'above and below the mean' criterion. The mean score of the respondents' ICTs usage was 22.5 therefore respondents with scores above 22.5 had high level of accessibility and vice versa.

\section{Results and Discussion}

\section{Available ICTs}

Table 1 shows that the most available ICTs among students were internet and mobile phone $(95.3 \%)$ respectively while email, radio and Ipad were available for $95.0 \%, 88.7 \%$ and $0.3 \%$ of the respondents respectively. This implies that the internet and mobile phone were the most available ICTs for the respondents. This could be as a result of versatility of mobile phone (smart and android type) as a multimedia communication device that could be available for telephoning, browsing and electronic mailing which has been channels for connectivity to distant areas, enhancement of education through faster message sharing and delivery of relevant information among people within a very short period of time (Namita, 2017). Also the same proportion of internet and mobile phone availability suggests that respondents with mobile phone might likely be using it for internet purpose in the study area. However, the versatility of Ipad is synonymous with that of mobile phone. The low availability of Ipad $(0.3 \%)$ might be due to the fact that greater percentage $(95.3 \%)$ of the respondents possess mobile phone probably due to the fact that mobile phone is cheaper and could be affordable by most students when compared with Ipad (Namita, 2017).

Table 1 further shows that the majority $(71.0 \%)$ of the respondents had high level of available ICTs in their various institutions. This depicts that the respondents' high 
Creative Commons User License: CC BY-NC-ND

Abstracted by: EBSCOhost, Electronic Journals Service (EJS),

Google Scholar, Journal Seek, Scientific Commons,

Food and Agricultural Organization (FAO), CABI and Scopus

http://eoi.citefactor.org/10.11226/v25i1
Journal of Agricultural Extension

Vol. 25 (1) January, 2021

ISSN(e): 24086851; ISSN(Print); 1119944X

http://journal.aesonnigeria.org

http://www.ajol.info/index.php/jae

Email: editorinchief@aesonnigeria.org

level of ICTs availability was due to a substantial state of provision of the needed ICTs on campuses by various institutions and the students' complementary efforts of improvising in cases where the institutions' ICTs facilities could not serve them efficiently. This corroborates Namita (2017) that Information and Communication Technology (ICT) has become an indispensable tool that has been given rapt attention in recent years.

\section{Table 1: Availability ICTs}

\begin{tabular}{lll}
\hline Available ICTs & $\begin{array}{l}\text { Percentage } \\
(\%)\end{array}$ & Rank \\
\hline Internet & 95.3 & $1^{\text {st }}$ \\
Mobile phone & 95.3 & $2^{\text {nd }}$ \\
E-mail address & 95.0 & $3^{\text {rd }}$ \\
Computer laboratory & 91.0 & $4^{\text {th }}$ \\
Laptop & 90.7 & $5^{\text {th }}$ \\
Printer & 89.3 & $6^{\text {th }}$ \\
Newspaper & 89.0 & $7^{\text {th }}$ \\
Magazine & 89.0 & $8^{\text {th }}$ \\
Radio & 88.7 & $9^{\text {th }}$ \\
Projector & 88.3 & $10^{\text {th }}$ \\
Television & 83.3 & $11^{\text {th }}$ \\
Scanner & 83.0 & $12^{\text {th }}$ \\
School intranet & 81.0 & $13^{\text {th }}$ \\
Bulletin & 80.3 & $14^{\text {th }}$ \\
IPod & 51.7 & $15^{\text {th }}$ \\
Digital camera & 45.2 & $16^{\text {th }}$ \\
CD-Rom & 35.2 & $17^{\text {th }}$ \\
Ipad & 0.3 & $18^{\text {th }}$ \\
Level of availability & Percentage & \\
\cline { 1 - 2 } High & 71.0 & \\
Low & 29.0 & \\
\hline
\end{tabular}

\section{Access to ICTs}

Table 2 shows the distribution of respondents by weighted scores in which mobile phone $(W M=0.58)$, radio $(W M=0.51)$ and personal e-mail account $(W M=0.50)$ were the most accessible ICTs while Ipod (WM=0.39) was the least accessed ICT tool by the respondents. This implies that respondents easily accessed information channels that personally belongs to them (phones, radio and e-mail accounts) probably due to the adequate knowledge of the various uses unlike information channels owned by their institutions (computer laboratories and projector) that might involve a lot of strict protocols and bureaucratic measures by the authorities for usage. The result of this study corroborates the assertion of Golam et al (2015) that agricultural students do access ICTs that is within their reach for the build-up of their career in spite of the availability of numerous ones at this global technology era. However, despite the fact 
Creative Commons User License: CC BY-NC-ND

Abstracted by: EBSCOhost, Electronic Journals Service (EJS), Google Scholar, Journal Seek, Scientific Commons,

Food and Agricultural Organization (FAO), CABI and Scopus
Journal of Agricultural Extension

Vol. 25 (1) January, 2021

ISSN(e): 24086851; ISSN(Print); 1119944X

http://journal.aesonnigeria.org

http://www.ajol.info/index.php/jae

Email: editorinchief@aesonnigeria.org

that IPod could be affordable as it was available for $51.7 \%$ of the students (Table 1 ), it could be inferred that the respondents do go about with it for leisure; the study further suggests that the poor access to the tool $(\mathrm{WM}=0.39)$ might probably be due to the fact that most of the information needed for their study were not package in music format. This supports the finding of Onodugo (2016) that the use of ICTs format is directly proportional to the information it could offer at a given period of time. From Table 2, the result shows that more than half (56.7\%) of the respondents had high level of access to the available ICTs. This implies that the respondents have the portent to be e-ready as they find ICTs very relevant to their different disciplines. Also, it further depicts that respondents' high availability of the ICTs tools has a correspondence influence on its accessibility; this agrees with the claim of Adeniyi and Yekinni (2015) that availability of ICTs is directly proportionate to its accessibility and vice versa. However, the study affirms that not all the available ICTs $(71.0 \%)$ were accessible (56.7\%).

Table 2: Access to ICTs

\begin{tabular}{ll}
\hline Access to available ICTs & $\begin{array}{l}\text { Weighted } \\
\text { mean }\end{array}$ \\
\hline Mobile phone & 0.58 \\
Radio & 0.51 \\
Personal e-mail account & 0.50 \\
Newspaper & 0.49 \\
Internet & 0.38 \\
Television & 0.47 \\
Magazine & 0.46 \\
Bulletin & 0.45 \\
School intranet & 0.44 \\
Laptop & 0.43 \\
Printer & 0.42 \\
Digital Projectors/interactive & 0.41 \\
white boards & \\
CD-Rom & 0.41 \\
Scanner & 0.40 \\
Ipad & 0.39 \\
Computer laboratory & 0.38 \\
Digital cameras & 0.37 \\
Ipod & 0.32 \\
\hline Level of accessibility & Percentage \\
\hline High & 56.7 \\
Low & 43.3 \\
\hline
\end{tabular}


Creative Commons User License: CC BY-NC-ND

Abstracted by: EBSCOhost, Electronic Journals Service (EJS),

Google Scholar, Journal Seek, Scientific Commons,

Food and Agricultural Organization (FAO), CABI and Scopus
Journal of Agricultural Extension

Vol. 25 (1) January, 2021

ISSN(e): 24086851; ISSN(Print); 1119944X

http://journal.aesonnigeria.org

http://www.ajol.info/index.php/jae

Email: editorinchief@aesonnigeria.org

\section{Purpose of ICT Usage}

Table 3 shows that respondents used ICTs to listen to news (WM=0.77), education/academics (WM $=0.70)$, for relaxation /entertainment $(\mathrm{WM}=0.69)$, and for social connection such as in social media (WM $=0.68)$. However, there was low usage of ICTs for business transaction by the respondents (WM $=0.62)$. This suggests that tertiary agricultural students use ICT tools to be aware of the current happenings around the globe, for leisure activities, enhancement of their academic prowess and for social interaction. This validates the findings of Namita (2017) and Orifah et al (2017) that students in higher institution of learning use ICT tools for gathering and disseminating information that are academic, leisure and social incline in nature. The result in Table 3 further shows that more than half $(51.3 \%)$ of the respondents had high level of purpose of using ICTs. This implies that the use of ICTs is relevant and needful for their academic endeavours which might be a form of empowerment for the respondents. The high purpose might be induced by the respondents' high availability and accessibility to the ICTs as established earlier (Table 1 and Table 2); hence it could be suggested that access to ICTs influences the purpose of use.

Table 3: Distribution of respondents' purposes of ICTs usage

\begin{tabular}{ll}
\hline Purpose items & Weighted mean \\
\hline News/information & 0.77 \\
Education/academics & 0.70 \\
Relaxation /entertainment & 0.69 \\
Communication/social connection & 0.68 \\
Learning & 0.66 \\
Presentations & 0.64 \\
Data storage & 0.63 \\
Business transaction & 0.62 \\
\hline Level of accessibility & Percentage \\
\hline High & 51.3 \\
Low & 48.7 \\
\hline
\end{tabular}

\section{Relationship between Socioeconomic characteristics and Purpose of ICTs Usage}

Table 4 reveals that there is positive significant relationship between respondents' monthly stipend $(r=0.200)$, state of institution $(x 2=8.060)$, religion $(x 2=222.660)$, marital status $(x 2=211.680)$, category of students' programme $(x 2=320.4608)$, type of institution $(X 2=56.000)$ and purpose of ICTs use. This implies that monthly stipend, state of institution, religion, marital status, category of students' programme and type of institution influences the purpose of utilisation of ICTs. However, the study reveals that respondents' age $(r=0.276)$, sex $(x 2=0.08 ; p=0.22)$ and level of programme $(x 2=0.822 ; p=-0.013)$ were not significantly related to the purpose of ICT use. This implies that neither the age, sex, nor level of respondents' programme was responsible for the purpose at which ICTs were deployed by the students in the study area. 
Creative Commons User License: CC BY-NC-ND

Abstracted by: EBSCOhost, Electronic Journals Service (EJS),

Google Scholar, Journal Seek, Scientific Commons,

Food and Agricultural Organization (FAO), CABI and Scopus

http://eoi.citefactor.org/10.11226/v25i1
Journal of Agricultural Extension

Vol. 25 (1) January, 2021

ISSN(e): 24086851; ISSN(Print); 1119944X

http://journal.aesonnigeria.org

http://www.ajol.info/index.php/jae

Email: editorinchief@aesonnigeria.org

Table 4: Relationship between Socioeconomic characteristics and purpose of ICTs usage

\begin{tabular}{lll}
\hline Variables & \multicolumn{2}{c}{ r-value } \\
\hline $\begin{array}{l}\text { Age } \\
\text { Level of programme }\end{array}$ & \multicolumn{2}{c}{0.276} \\
$\begin{array}{l}\text { Monthly stipends } \\
\text { Variables }\end{array}$ & \multicolumn{2}{c}{$0.822^{*}$} \\
\hline Sex & $0.200^{*}$ & \\
Religion & 8.833 & Df \\
State & $222.660^{*}$ & 1 \\
Marital status & 8.060 & 2 \\
Category of students & $211.680^{*}$ & 2 \\
Type of institution & $320.4608^{*}$ & 1 \\
\hline
\end{tabular}

*P $\leq 0.05$

\section{Difference between Students' Purpose of ICTs Usage across States.}

Table 5 shows that significant $(\mathrm{F}=21.102)$ difference existed between tertiary institution students' purpose of ICTs use across the state. This means that agricultural tertiary institution students differ in their purpose of ICTs utilisation across the states. Result of further analysis (post hoc) in Table 6 revealed the differences between tertiary institution students' purpose of ICTs use across the States such that, there was significant difference between respondents in Ondo and Ekiti (Mean difference $=4.39$ and between respondents' in Ekiti and Oyo (Mean difference $=3.90$ ), there was no significant difference between respondents in Oyo and Ondo (Mean difference=0.49). This shows that respondents in Ondo and Ekiti and Ekiti and Oyo differs in the purpose with which they put their ICTs to use as agricultural students while the students of Oyo and Ondo has the same trend of purpose of ICTs usage in their various institutions.

Table 5: Difference between students' purpose of ICTs usage across states

\begin{tabular}{llll}
\hline Source of variation & $\begin{array}{l}\text { Mean } \\
\text { square }\end{array}$ & Df & F- value \\
\hline Between groups & 505.123 & 2 & $21.102^{*}$ \\
Within groups & & 381 & \\
\hline
\end{tabular}

${ }^{\star} \mathrm{P} \leq 0.01$.

Table 6: Difference between students' purpose of ICTs usage across states

\begin{tabular}{llll}
\hline $\begin{array}{l}\text { State category } \\
(\mathrm{I})\end{array}$ & $\begin{array}{l}\text { State } \\
\text { category } \\
(\mathrm{J})\end{array}$ & $\begin{array}{l}\text { Mean } \\
\text { difference } \\
(\mathrm{I}-\mathrm{J})\end{array}$ & $\mathrm{p}$-value \\
\hline Ondo & Ekiti & $4.39000^{*}$ & 0.000 \\
Ekiti & Oyo & $3.90000^{*}$ & 0.000 \\
Oyo & Ondo & 0.49000 & 0.460 \\
\hline
\end{tabular}


Creative Commons User License: CC BY-NC-ND

Abstracted by: EBSCOhost, Electronic Journals Service (EJS),

Google Scholar, Journal Seek, Scientific Commons,

Food and Agricultural Organization (FAO), CABI and Scopus

http://eoi.citefactor.org/10.11226/v25i1
Journal of Agricultural Extension

Vol. 25 (1) January, 2021

ISSN(e): 24086851; ISSN(Print); 1119944X

http://journal.aesonnigeria.org

http://www.ajol.info/index.php/jae

Email: editorinchief@aesonnigeria.org

\section{Difference between Students Purpose of ICTs Usage Across Types of Institutions}

A test of difference between students' ICTs usage purposes across the Institutions in Table 7 shows that there was no significant $(F=1.074)$ difference between both categories. This means that tertiary agricultural students' do not differ in their purpose of ICTs utilisation. Result of further analysis (post hoc) in Table 8 reveals the insignificant differences between tertiary institution students' purpose of ICTs use across the Institution such that, there was no significant difference between respondents in University and Polytechnic (Mean difference=1.03750); between respondents' in Polytechnic and College of Education (Mean difference $=0.55417$ ), and between respondents in college of Education and University (Mean difference $=0.48333$ ). This implies that irrespective of the respondents' type of institutions, the purpose of ICTs usage was constant for the agricultural students (Onodugo, 2016).

Table 7: Difference between students' purpose of ICTs usage across types of institution

\begin{tabular}{llll}
\hline Source of variation & $\begin{array}{l}\text { Mean } \\
\text { square }\end{array}$ & Df & F- value \\
\hline $\begin{array}{l}\text { Between groups } \\
\text { Within groups }\end{array}$ & 58.316 & 2 & 1.074 \\
\hline${ }^{*} \mathbf{P} \leq 0.05$ level & & 297 & \\
\hline
\end{tabular}

${ }^{*} \mathrm{P} \leq 0.05$ level

Table 8: Difference between students' purpose of ICTs usage across types of institution

\begin{tabular}{|c|c|c|}
\hline $\begin{array}{l}\text { Institution } \\
\text { category } \\
\text { (I) }\end{array}$ & $\begin{array}{l}\text { Institution } \\
\text { category } \\
\text { (J) }\end{array}$ & $\begin{array}{l}\text { Mean difference } \\
\text { (I-J) }\end{array}$ \\
\hline University & Polytechnic & 1.03750 \\
\hline Polytechnic & $\begin{array}{l}\text { College of } \\
\text { Education }\end{array}$ & 0.55417 \\
\hline $\begin{array}{l}\text { College of } \\
\text { education }\end{array}$ & University & 0.48333 \\
\hline
\end{tabular}

${ }^{*} \mathrm{P} \leq 0.05$ level

\section{Conclusion and Recommendations}

The most available ICTs for the agricultural tertiary students are internet and mobile phone while the most commonly accessed ICTs are mobile phone and radio. Students' purposes of ICTs usage are for information, academic and entertainment based on their monthly stipend, state of institution, religion, marital status, category of students' programme and type of institution though with significant difference across the states of institution. Since ICTs are used for beneficial purposes, it is recommended that ICTs should be adapted, applied and incorporated into tertiary institutions' curricula across the nation. Also, Music that is in line with the students' 
Creative Commons User License: CC BY-NC-ND

Abstracted by: EBSCOhost, Electronic Journals Service (EJS), Google Scholar, Journal Seek, Scientific Commons,

Food and Agricultural Organization (FAO), CABI and Scopus

http://eoi.citefactor.org/10.11226/v25i1
Journal of Agricultural Extension

Vol. 25 (1) January, 2021

ISSN(e): 24086851; ISSN(Print); 1119944X

http://journal.aesonnigeria.org

http://www.ajol.info/index.php/jae

Email: editorinchief@aesonnigeria.org

course content should be composed to enhance the use of Ipod by the tertiary agricultural students for academic purpose.

\section{References}

Adavbiele, J. A. (2016). The use of ICT to enhance university education in Nigeria. International Journal of Education, Learning and Development Vol.4, No.5, June 2016 Published by European Centre for Research Training and Development UK (www.eajournals.org) 1SSN 2054-6297(Print), ISSN 2054-6300(Online) pp.1-11.

Adeniyi, R. T. and Yekinni, O. T. (2015). Arable crop farmers' characteristics affecting the utilization of information and communication technology for agricultural marketing information in Oyo State, Nigerian. Journal of Rural Sociology, 15(2), 23-29.

Golam, S. F, Arifa. R. Iqbal. H and Arifur. R. (2015). Application of ICT at the Tertiary Education: Exploring the Utilization and the Attitudes of Teachers and Students International Journal of Education and Applied Research (IJEAR) Vol. 5, Issue 2, July - Dec 2015. ISSN: 2348-0033 (Online) ISSN: 2249-4944 (Print). Pages 28-34.

Hamilton-Ekeke, J. T, and Mbachu C. E. (2015). "The Place of information, communication and technology (ICT) in teaching and learning in Nigerian Tertiary Institutions." American Journal of Educational Research, vol. 3, no. 3 (2015): 340-347. doi: 10.12691/education-3-3-13.

Namita, S. (2017). The role and impact of ICT in improving the quality of education: an overview. International Journal of Engineering Sciences \& Research Technology. DOI: 10.5281/zenodo.439205. 6(3): March, 2017. ISSN: 2277-9655. Pp 501-503

Onodugo, I. C. (2016). Impact of information and communication technology (ICT) on teaching and learning in Nigerian tertiary institutions. International Journal of Multidisciplinary Education and Research. Volume 1; Issue 1; January 2016; Page No. 01-06.

Orifah, M. O., ljeoma, M. C., Olajide, B. R. and Wigwe, C. C. (2017). Use of social media by agricultural undergraduate students in selected universities in Nigeria. Journal of Agricultural Extension. Vol. 21 (2) June, 2017. ISSN (e): 24086851; ISSN (Print); 1119944X. https://dx.doi.org/10.4314/jae.v21i2.10. Pp 120-128. 